\author{
E. А. Мишина \\ Институт русского языка им. В. В. Виноградова РАН \\ (Москва, Россия) \\ kmishina@mail.ru
}

\title{
ОТРИЦАТЕЛЬНЫЙ ИМПЕРАТИВ В ДРЕВНЕРУССКОМ ЯЗЫКЕ
}

Настоящая статья посвящена исследованию функционирования форм императива под отрицанием в древнерусском языке. В современном русском языке отрицательный императив образуется преимущественно от глаголов несовершенного вида, при этом формы императива под отрицанием от глаголов разных видов имеют разное значение: императив НСВ - прохибитивное значение (выражается запрет), императив СВ - превентивное значение (выражается предостережение). В древнерусском языке отрицательный императив НCВ также преобладает, однако отрицательный императив СВ употребляется шире, чем в современном русском. Проведенный анализ показывает, что в древнерусском языке еще не сформировалась функциональная оппозиция превентив (CB) vs. прохибитив (HCB), вырисовывающаяся довольно чётко в современном русском языке: в отрицательных контекстах древнерусские тексты демонстрируют более свободную, по сравнению с современным русским языком, конкуренцию между СВ и НСВ, при этом семантическая разница между формами отрицательного императива разных видов была во многом обусловлена различиями в аспектуальной семантике, а прагматические функции накладывались дополнительно. В дальнейшем в процессе исторического развития СВ в императиве под отрицанием сузил свой функциональный (иллокутивный) диапазон и стал реже употребляться.

Ключевые слова: отрицание, простой императив, перифрастический императив, превентив, прохибитив, глагольный вид, древнерусский язык.

В сочетании с отрицанием императив обозначает побуждение к несовершению действия. В современном русском языке отрицательный императив образуется преимущественно от глаголов несовершенного вида, причем отрицательные формы императива от глаголов разных видов имеют разное значение, см. [Булыгина 1982: 75; Храковский, Володин 1986; Бирюлин, Храковский 1992: 35; Гусев 2013: 61-62; Zorikhina Nilsson 2013; Добрушина 2014] и др. Отрицательный императив НСВ имеет прохибитивное значение, то есть выражает запрет на совершение 
действия ('не делай Р'). Употребление НСВ в современном русском языке является обычным для запрета, СВ в значении прохибитива в большинстве случаев невозможен, ср.: Не включай свет! (НСВ) vs. *Не включи свет! (CВ). Форма императива от глагола СВ в сочетании с отрицанием, как правило, имеет превентивное значение, выражает предостережение (Не упади! Не простудись). Значение превентива двухкомпонентно: (а) говорящий сообщает о том, что может произойти некоторое нежелательное событие Р и (б) побуждает сделать так, чтобы Р не произошло [Гусев 2013: 61-62]. Семантическая двухкомпонентность превентива (выражается опасение возможного нежелательного события + предостережение) позволяет считать превентив частным случаем апрехенсива (выражается опасение возможного нежелательного события) ${ }^{1}$. Как правило, значение прохибитива и превентива связывают с контролируемостью (прохибитив) и неконтролироемостью (превентив) действия, несовершение которого пытается каузировать говорящий, ср. (1а) и (1б), или всей ситуации в целом (1в):

(1а) Не поливай мой кактус чащце двух раз в месяч! - контролируемое действие;

(1б) Не забудь полить мой кактус! - неконтролируемое действие;

(1в) Смотри не полей мой кактус! Я его уже поливал вчера - контролируемое действие, неконтролируемая ситуация.

Однако в отношении контролируемости / неконтролируемости нужны определенные оговорки. Несмотря на то, что данная функциональная дистрибуция представлена в современном русском языке в качестве магистральной тенденции, существуют исключения и проблемные контексты. Кроме того, для успешности императивной формы параметр контролируемости ситуации говорящим (или же его уверенность в том, что он ее контролирует) в определенном смысле обязателен, см. об этом ниже в п. 2.2 .

В восточнославянских памятниках древнерусского периода, как и в современном русском языке, отрицательный императив от глаголов НСВ выражал значение прохибитива (см. п. 1). Что касается формы императива СВ, то в сочетании с отрицанием она могла выражать как превентивное (см. п. 2.1-2.2), так и прохибитивное значение (см. п. 2.2-2.3). В настоящей статье анализ сосредоточен на функционировании форм императива 2 л.

\section{1. Отрицательный императив НСВ (прохибитив)}

В древнерусских текстах отрицательный императив от глаголов НСВ, как и в современном русском языке, выражает прохибитивное значение: говорящий может пытаться каузировать прекращение совершения действия, происходящего в момент речи (2)-(3) или несовершение некоторого действия (или действий) в ближайшем

${ }^{1}$ В [Добрушина 2006; Добрушина, Даниэль 2008] предлагается считать апрехенсив и превентив двумя самостоятельными значениями, однако приводимые в этих работах аргументы свидетельствуют, скорее, не о параллельной модели, а о модели по типу матрёшки. 
будущем (4)-(7), причем в последнем случае речь, как кажется, чаще идет о потенциально многократных ситуациях. Временной интервал, относящийся к будущему, может практически соприкасаться с моментом речи (начинаться на его границе), как в (7) - и сейчас не слушай, и в будущем. Такого рода контексты встречаются в повествовательных жанрах (летописях, житиях, повестях) и грамотах:

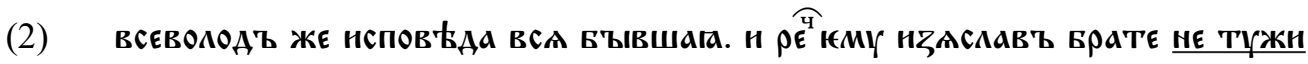
(ПВЛЛ, л. 67) — «Всеволод же рассказал ему о всем случившемся. И сказал ему Изяслав: Брат, не печалься!»;

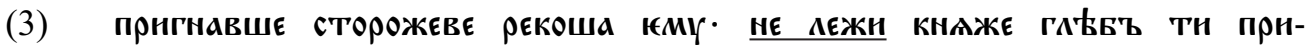
шєкъ на та (Сузд. лет., Л. 106об. .=Киев. лет., л. 131об.) - «Примчавшись, сторожа сказали ему: Не лежи, князь, ведь Глеб пришел воевать с тобой»;

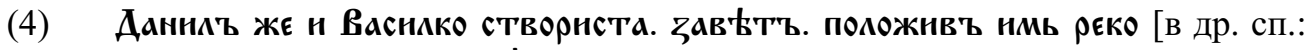

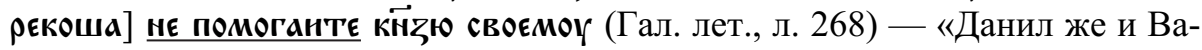
силко составили договор, наказав им: Не помогайте князю своему»;

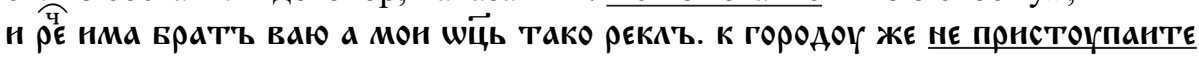
Аокольже прндог (Киев. лет., Л. 122) — «И сказал им: Брат ваш, а мой отец, так сказал: “К городу же не приступайте, пока не приду”»;

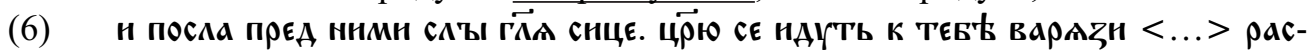
ТОчн га разно. а сЊмо не ПцЩан ннеАнного (ПВЛЛ, Л. 25) - «И ПОсЛаЛ ПОред ними послов, говоря так царю: Вот, идут к тебе варяги, <.. > разгони их, а сюда ни одного не пускай»;

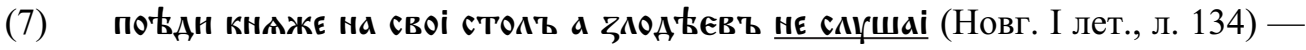
«Поезжай, князь, на свой престол, а злодеев не слушай».

Часто отрицательный императив НСВ употребляется для запрета нелокализованного во времени действия, потенциально многократного (8)-(12). Контексты такого типа редки в летописях, но довольно широко представлены в текстах, содержащих различные поучения («Пчела», «Повесть об Акире Премудром», «Слово» и «Моление» Даниила Заточника, сочинения Кирилла Туровского, «Вопрошание Кирика, Саввы и Ильи», «Поучение Владимира Мономаха» и др.), причем в этом значении в древнерусских текстах НСВ частотнее СВ (приблизительно $67 \%$ : 33 \%), также возможного в прохибитивном значении (см. п. 2.3):

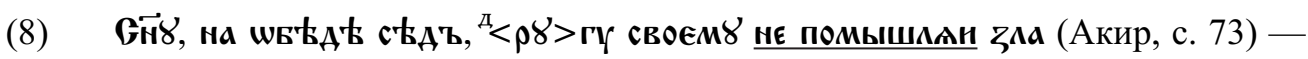
«Сын, сидя на обеде, другу своему не желай зла»;

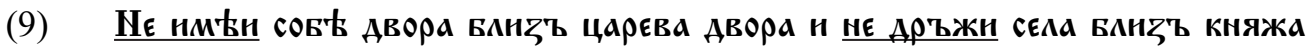
сєка (Даниил Заточник, с. 20-21) — «Не строй (букв. не имей) свой дом рядом с царским двором, и не держи села рядом с княжьим селом»;

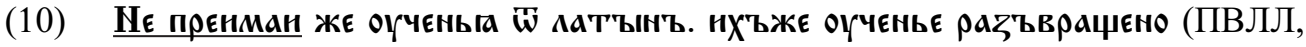
л. 39об.) - «Не перенимай учения от латинян: их учение развращено»;

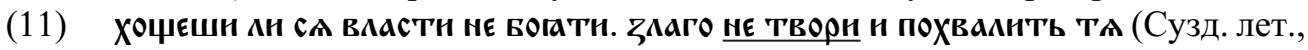
л. 245об.) — «Если хочешь не бояться власти, злого не делай, и похвалит тебя»; 


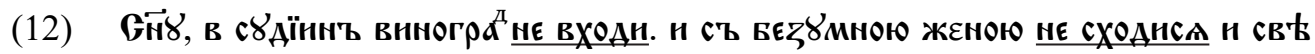
[вместо: свЊта] с нею не творн (Акир, с. 75) - «СЫн, в виноградник судЬИ не входи, и с безумною женою не сходись, и совет с ней не твори».

Как показано в [MacRobert 2013: 283-285], в старославянских текстах отрицательные императивы HCB употребляются в тех же значениях, что и в древнерусском (примеры взяты из работы К. М. МакРоберт). С одной стороны, они выражают запрет действий, имеющих место в момент речи (нє А къ мьн' Мк 10:14) или в будущем, так что точкой отсчета является настоящий момент (ндн и отъсек' не съгрђшан Ин 8:11), а с другой - выражают общий За-

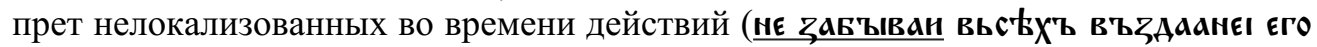
Пс. 102.2). Последний пример демонстрирует наиболее частотное значение отрицательного императива НСВ в старославянском.

\section{2. Отрицательный императив СВ}

Такой четкой функциональной дистрибуции СВ (превентив) vs HCB (прохибитив), как в современном русском языке, в древнерусских текстах не обнаруживается. По-видимому, данная тенденция развилась позднее. Связано это, прежде всего, с более широким, по сравнению с современным состоянием, функционированием императивных форм СВ: они могли употребляться не только в превентивном, но и в прохибитивном значении. Кроме того, далеко не всегда выбор и употребление СВ или НСВ можно объяснить различием между случаями, когда речь идет о контролируемом или неконтролируемом действии или ситуации, а скорее различиями в аспектуальной семантике ${ }^{2}$. Дополнительная сложность в установлении значения в древнерусских текстах связана с тем, что в них отсутствуют такие лексические показатели, как смотри, только и др. (Смотри не упади! Только не проcmyдucb!), которые довольно часто (хотя и не обязательно) ${ }^{3}$ сопровождают употребление превентивов СВ в современном русском языке.

\section{1. Превентив}

В ряде древнерусских контекстов (их число невелико) у форм императива $\mathrm{CB}$, как и в современном русском языке, можно усмотреть превентивное значение в том случае, когда речь идет о предупреждении неконтролируемых или плохо контролируемых нежелательных событий, например:

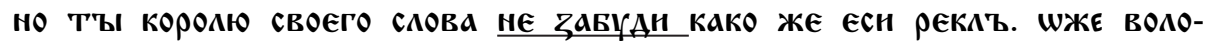

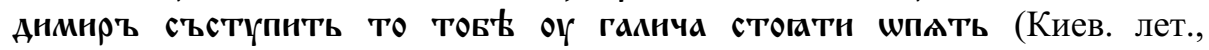

${ }^{2} \mathrm{O}$ том, что в славянских языках оппозиция превентив (CB) : прохибитив (HCB) укладывается в более общие тенденции аспектуального выбора - в частности, превентивное значение является следствием комбинации отрицания и совершенного вида для обозначения событий, локализованных во времени, см. [Wiemer, в печати].

${ }^{3}$ См. [Зализняк Анна, Шмелев 2000: 41; Добрушина, Даниэль 2008]. 
л. 163-163об.) - «Но ты, король, своего слова не забудь, какое ты произнес: если Владимир нарушит клятву, то ты снова станешь у Галича»;

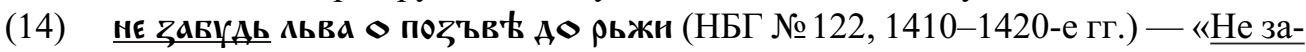
будь Льва в связи с вызовом [на суд]».

В приведенных контекстах речь идет о предупреждении, попытке каузации несовершения единичного действия в конкретной ситуации в будущем ('не забудь, когда будет нужно / когда придет время’). В сходных контекстах с конкретно-референтным субъектом возможен и НСВ (не забываи ${ }^{4}$ ). В этом случае, по всей вероятности, происходит совмещение семантики запрета (говорящий посылает слущающему определенный директивный посыл, выражающий его желание: 'не забываи' = 'помни') с семантикой предостережения', ср.:

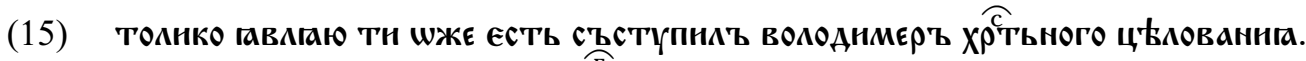
но тЫ ТОлнко не ЗаБЫван своЕ СКова. ЕЖе Есн РекАЪ (КИеВ. ЛеТ., Л. 163об.) «Сообщаю тебе, что Владимир нарушил клятву. Но ты только не забывай своих слов, которые ты произнес!»;

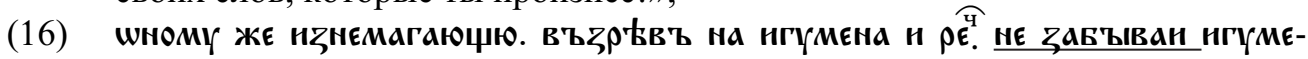
не Єже мн ксн шь'фщаһ (ПВЛЛ, Л. 64) - «А тот, изнемогая, посмотрев на игумена, сказал "Не забывай, игумен, что ты мне обещал”».

Приведенные примеры с НСВ близки также к другим контекстам узуального типа с референцией к ситуации, нелокализованной во времени (17)-(19): говорящий побуждает адресата не совершать действие каждый раз, когда это может быть актуально ('не забывай никогда = всегда помни') 6 , ср.:

(17) ТЕБ' ЖЕ. Чव̆ МОЛЮСА. ВННМАН СЕБЕ. НЕ ЗАБЫВАН КАЮКЪ ЕГО. БАЮАН ЖЕ ВЪ МАРТТ и треЗвнсА О всемь (ЖАЮ, 1311-1313, с. 223) - «МоЛЮ Же тебя, чадо, следИ за собой, не забывай козней его, будь мудрым и бдительным во всем»;

(18) снроты мнхун. БОхАчнХъ не заБыван. вАовамъ помаГан (ЖАЮ, 60356036, с. 444) - «Сирот милуй, болеющих не забывай, вдовам помагай»;

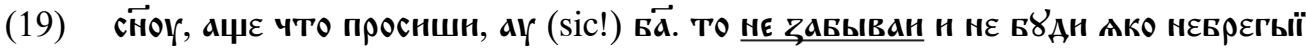
(Акир, с. 47) - «Сын, если просишь что-то у Бога, то не забывай (этого) и не будь, как тот, кто пренебрегает (его дарами)».

Таким образом, как видно из приведенных примеров, выбор между СВ : НСВ зависел не только от выражаемого значения «превентив : прохибитив»,

\footnotetext{
${ }^{4}$ Следует отметить, что в древнерусских текстах не встретилось форм императива от глагола забывати без отрицания. В современном русском языке без отрицания эта форма также практически не встречается.

5 Такое совмещение возможно и в современном русском языке, о чем свидетельствует сочетание известных лексических показателей превентива (смотри, только) не только с формами императива СВ, но также и НСВ (такие употребления зафиксированы, например, в НКРЯ), ср.: Смотри/Только не забудь нас!: Смотри/Только не забывай нас!

${ }^{6}$ Как отмечается в [Zorikhina Nilsson 2013: 90] для выражения запрета повторяющегося действия во всех современных славянских языках выбирается исключительно НСВ.
} 
но и от выражаемой аспектуальной семантики: СВ (конкретная единичная ситуация в будущем) vs HCB (нелокализованная во времени ситуация). В действительности для пары не забудь : не забывай (а также ряда других глаголов) похожее положение дел имеет место и в современном русском языке. Так, существует довольно много контекстов, когда выбор СВ или НСВ можно объяснить не столько функционально-дискурсивной оппозицией «превентив : прохибитив», сколько, скорее, особенностями аспектуальных значений. Например, в ситуации с конкретной референцией к единичной ситуации в будущем (20а) возможен императив СВ и невозможен $\mathrm{HCB}$, в то время как в контекстах с референцией к обобщенной, генерической ситуации возможен только НСВ (20б). При этом форма императива $\mathrm{CB}$ в таких случаях чаще (хотя и не всегда) сочетается с инфинитивом $\mathrm{CB}$, а форма императива НСВ - с инфинитивом НСВ. Употребление СВ (наряду с НСВ) возможно также в некоторых типах контекстов, например в слоганах, призывах типа (20в), выражающих нелокализованное во времени действие. В этом случае значение императива СВ оказывается близким к наглядно-примерному значению, когда типичное выражается через единичное, в отличие от НСВ, более характерного для обозначения повторяющейся или генерической ситуации, ср.:

(20а) Маша, уходя с кухни (когда будешь уходить с кухни), не забудь выключить свет! (в этот конкретный раз);

Петя, пора спать! Не забудь почистить зубы перед сном! (в этот конкретный раз).

(20б) Маша, уходя с кухни, не забывай выключать свет! (всегда, когда уходишь); Петя, не забывай чистить зубы перед сном! (всегда, когда ложишься).

(20в) Уходя с кухни, не забывай / не забудь выключить свет! (каждый раз) Ложась спать, не забывай / не забудь почистить зубы перед сном!

Приведем еще несколько контекстов, в которых у императивов СВ можно усмотреть превентивное значение. В примере (21) первая форма отрицательного императива НСВ (не мори), по-видимому, имеет прохибитивное значение (побуждение к прекращению контролируемого действия: морить или не морить себя голодом князь решает сам и может этот процесс контролировать), в то время как второй отрицательный императив СВ (не помори) имеет скорее превентивное значение в ситуации, когда речь идет о предотвращении возможного, но не планируемого действия: у князя нет цели специально уморить голодом людей в городе, но если осада будет продолжена, то это может произойти. Аналогичная ситуация представлена в примере (22): у князя, к которому обращаются его люди, нет цели ни погибнуть самому, ни погубить свою дружину, но, с точки зрения говорящих, вероятность такая есть:

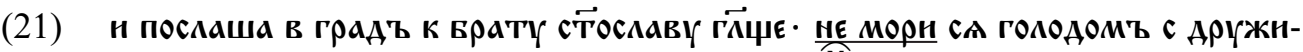

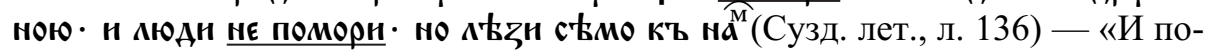
слали в город к брату Святославу, говоря: “Не мори себя с дружиною голодом, и людей своих не умори, но иди сюда к нам”»; 


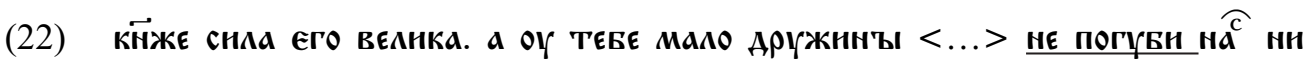
самъ нє погыни (Киев. лет., л. 145об.) — «Князь, сила его велика, а у тебя мало дружины $<\ldots>$ Не погуби нас и сам не погибни!».

Превентивное значение (предупреждение наступления неконтролируемого действия) у отрицательного императива СВ можно усмотреть и в контекстах (23), (24a), (25a), (26). Во всех приведенных примерах с СВ имеет место референция к конкретной единичной ситуации в будущем, в отличие от контекстов с формой императива НСВ (с прохибитивной семантикой), имеющей референцию к моменту речи (24б), (25б) или к нелокализованной во времени ситуации (256), ср.:

(23) КЪ ГОрЪ БОлюБНЫХҚ АОБРОА ТТЕАНН АОНАЕШН. НЪ И ТОГАव НЕ РАСКАБН СОБЕ. нъ потьрпн (Кирилл Туровский. «Сказание о черноризском чине») - «Когда дойдешь до горы богоугодных добродетелей, и тогда не потеряй твердости (букв. не расслабься), но потерпи»;

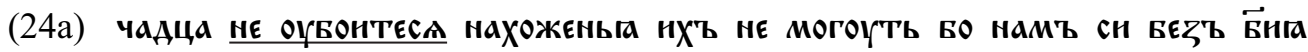
попоуџєньга створнти ннчтоже (ЖЛР, Л. 95) - «Чада, не пугайтесь/испугайтесь (букв. не убойтесь $\left.{ }^{7}\right)$ их, так как не могут они без Божьего попущения ничего сделать», ср. с НСВ в (24б) и (24в);

(24б) Н РЕчЕ АН̈ГАЪ НЕ БОНСА. НАН ПГТЕМЪ ТВОНМЪ КЪ НЕРАМУ (ПВЛИ, Л. 98Об.) «И сказал ангел: “Не бойся! Иди своим путем к Иерусалиму”»;

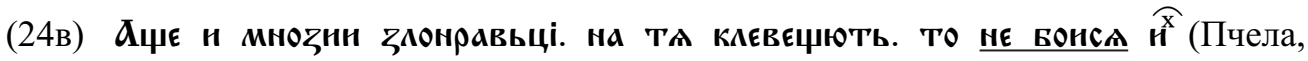
c. 661) — «И если многие злые на тебя клевещут, то не бойся их»;

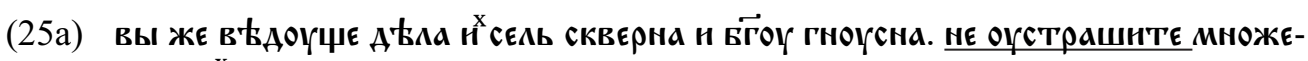
ства й (ИИВ, л. 425б) - «Вы же, знающие дела их, столь скверные и Богу гнусные, не устрашитесь их количества», ср. с НСВ в (25б);

(25б) В Ц арапаръ, ШБразомъ слнцено [ВМесто: слнченъ] мнЪ, и Повїненъ Есть

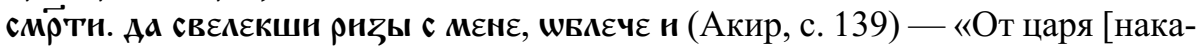
зания] не бойся (букв. не устрашайся), так как есть в моей тюрьме человек, зовут его Арапар, внешне похожий на меня. И он приговорен к смерти. Так что сняв с меня одежду, одень его»;

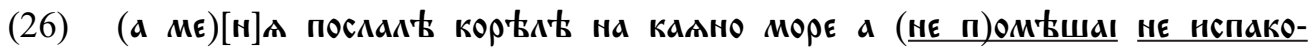
СТН КаАнеЦамо ни СОБн ПрНсловнА возмн (НБГ №286, 1360-1380 ГГ.) «[А меня (?)] послали к карелам на Каяно море. А ты смотри не помешай, не напакости каянцам и себе не заполучи худой славы».

${ }^{7}$ Ср. современную диалектную и просторечную форму: бой, если забоишься! (НКРЯ: В. Осеева. Динка). 


\section{2. Превентив или прохибитив?}

Как упоминалось в начале статьи, прохибитив и превентив обычно противопоставляют по контролируемости (прохибитив) / неконтролируемости (превентив) действия, несовершение которого пытается каузировать говорящий [Бирюлин, Храковский 1992: 35; Гусев 2013: 61]. В то же время, неконтролируемость события (наступление которого пытается предотвратить говорящий) противоречит общему требованию контроля говорящего над ситуацией, что, в свою очередь, является необходимым условием успешности пове-

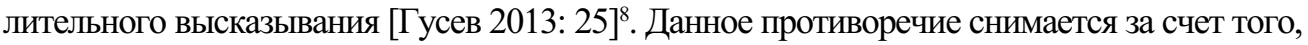
что действие, обозначенное превентивом, выступает в действительности как относительно контролируемое. Говорящий полагает, что имеет опосредованный контроль над ситуацией, что его призыва достаточно, чтобы на нее повлиять, из чего, в свою очередь, следует, что говорящий не считает, что у адресата нет никакого контроля над ситуацией, а скорее, наоборот: по мнению говорящего, адресат в состоянии повлиять на ситуацию и не допустить нежелательного действия, совершив (или не совершив) ряд контролируемых действий [Бирюлин, Храковский 1992: 38]. Таким образом, формы императива СВ под отрицанием совмещают семантику неконтролируемости выражаемого действия (лексическая семантика) с внешним контролем говорящего над ситуацией в целом (семантика императива). Употребление отрицательного императива СВ от глаголов с контролируемой семантикой обозначаемого действия возможно в современном русском языке в том случае, если в ситуацию добавляется какой-то элемент неконтролируемости (Смотри, не подари ему книгу, которая у него уже есть!, пример из [Зализняк Анна, Шмелев 2000: 41]).

В древнерусских текстах отрицательные императивы СВ от глаголов с контролируемой семантикой могли употребляться шире, чем в современном русском языке. В ряде контекстов значение императива СВ трудно однозначно определить как превентивное или прохибитивное, и таких контекстов больше, нежели тех, в которых превентивное значение очевидно (см. выше п. 2.1). В примерах (27)-(31) у отрицательных

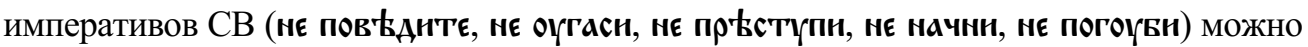
предположить превентивное значение - попытку предупредить наступление случайного действия (Не проболтайтесь никому ненароком!; Не загаси случайно свечу; Смотри, не скажси что-нибудь поперек; Только не начни ничего хулить ненароком). С позиции носителя современного русского языка такое прочтение может казаться весьма вероятным, однако однозначных доказательств такому прочтению нет. Равновероятно здесь можно усмотреть и запрет (предупреждение нежелательных, но вполне контролируемых действий): князь ожидает, что его слуги могут/захотят сознательно рассказать о его приказе кому-нибудь; женщина может по той или иной причине решить погасить свечу; посланные могут сознательно начать перечить или возмущаться, и т.п.:

WН ЖЕ РЧЕ НМЪ НЕ ПОВ'АНТЕ ННКОМУЖЕ. ШЕАШЕ ОУБННТЕ БРАТТ МОЕГО БОРНca (ПВЛИ, л. 50) - «Он же сказал им: "Не рассказывайте / смотрите,

${ }^{8}$ Как отмечается в [Добрушина 2006: 57], полностью неконтролируемое действие не может быть передано с помощью превентива ( ${ }^{*}$ Смотри, не умри!). Правда, с иронической интонацией в качестве шутки такое высказывание представляется возможным. 
не расскажите (букв. не расскажите) никому. Пойдите убейте брата моего Бориса"»;

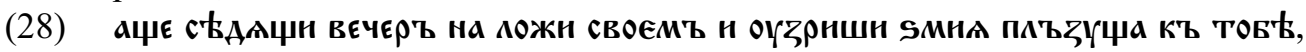

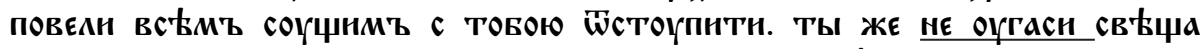

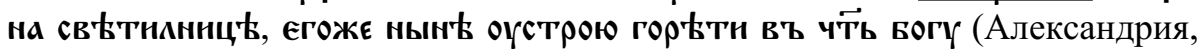
с. 5) - «Если, сидя вечером на ложе своем, увидишь змея, ползущего к тебе, прикажи всем, кто будет с тобою, отойти. Ты же не гаси / смотри, не загаси (букв. не загаси) свечу на светильнике, который нынче зажгу в честь бога»;

(29) Н БОРЗО ПААН НА АНЦН СВОЕМЬ. Н ПОКАОННСА МЦЖУ ТОМУ. Н ВСЕ ЕЖЕ РЕЧЕТЬ К ТОБ' СТВОрн не прЊСТУПн н оумерши [В др. сП.: огмрєшн] (ПВЛИ, Л. 98об.) - «И ТОТчас ПаДИ НИЦ и поклонись мужу тому, и все, что он скажет тебе, исполни. Не нарушай / Смотри, не нарушь (букв. не преступи) приказаний его. Если же нарушишь, в тот же день умрешь»;

(30) КГАА ЖЕ ПРНАЕШН К НЕМУ. НЕ НАЧНН ННКАКА АНХХГа САОВЕСА. НЪ АХХМЬ СЪТ ТЕНЪМЬ

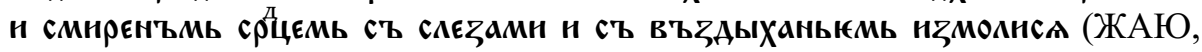
4914-4916, с. 394) - «Когда же придешь к нему, не начинай / только не начни (букв. не начни) [говорить] никаких дурных слов, но с духом сокрушенным и со смиренным сердцем, со слезами и воздыханием помолись»;

(31) ЛЕВЪ КНАҚЬ. ПОСАА СЕМЕНА СВОЕГО АААЬКОВНЧА. КО СН̈ОВН СВОЕМОУ > .. > РЕКА

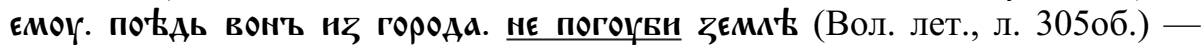
«Князь Лев послал Семена, сына своего воспитателя, к своему сыну, говоря ему: "Поезжай вон из города, не губи (букв. не погуби) земли”».

Можно предположить, что приведенные контексты демонстрируют сочетание значения запрета, выражаемого формой императива (выражается предписывающая воля говорящего), и предостережения, выражаемого СВ в комбинации с отрицанием (имеет место желание предотвратить нежелательное действие в случайной ситуации $)^{9}$. Кроме того, следует отметить, что во всех примерах, как и в приведенных выше в п. 2.1, имеет место референция к единичному действию в будущем.

В старославянском языке, как отмечается в [MacRobert 2013: 286], также встречаются употребления отрицательного императива $\mathrm{CB}$, в семантику которых включается компонент предостережения, ср. (примеры взяты из работы К. М. МакРоберт):

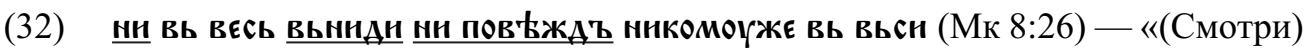
не заходи (букв. не войди) в деревню, и не рассказывай (букв. не расскажи) никому в деревне»;

9 Следует отметить, что семантический компонент «ожидания» наступления некоторого события практически всегда возникает в контексте «отрицание + глагол СВ» [Зализняк Анна 2015: 315] вследствие того, что компонент намерения осуществить действие или его ожидания входит в презумптивную часть значения $\mathrm{CB}$, которая не попадает в сферу действия отрицания [Падучева 1996: 54-56; 2013: 203]. У отрицательного императива СВ это семантическое наращение появляется также вследствие двухкомпонентности его значения. Под отрицание может попасть только одна из частей значения, и часть, содержащая информацию о возможном наступлении некоторого неблагоприятного события, не попадает под отрицание (см. об этом ниже в п. 2.3.2). 


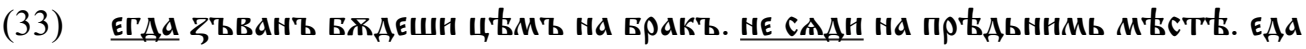

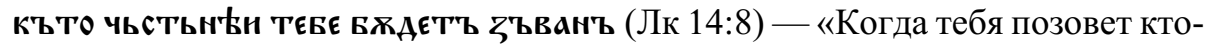
нибудь на свадьбу, не садись (букв. не сядь) на лучшее место, вдруг окажется, что приглашен кто-то важнее тебя».

В (32)-(33), как и в приведенных выше контекстах (27)-(31), представлен, скоpee, сплав превентивного и прохибитивного значений, а не только «чистое» предупреждение. В (33), в отличие от приведенных выше примеров (27)-(31), имеет место референция к нелокализованной во времени ситуации, обычно свойственная контекстам с НСB, ср. (8)-(12). По-видимому, употребление императива СВ в (33) может быть объяснено функционированием в кратно-парной конструкции (егда ... mо), где в придаточной части (со значением условия) употреблен презенс СВ (вжАєши), мотивирующий (или даже «навязывающий») выбор императива СВ в главной части, ср. со сходными примерами из древнерусских памятников:

(34) ДКОЖЕ БО неВОАЪ НЕ УАЕРЖНТЪ ВОАЫ, ТОЧіЮ ЕАННЫ РЫБЫ, ТАКО Н ТЫ, КНЯЖЕ,

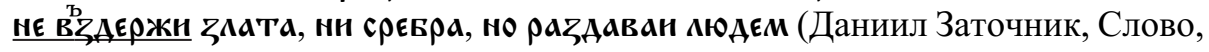
с. 53) - «Как невод не удержит воды, только рыбу, так и ты, князь, не удержи ни золота, ни серебра, но раздавай людям»;

(35) ащЕ 弓иова прндеть, то не порайса (Акир, с.31) - «Если случится что-либо злое, то не возрадуйся».

В [Wiemer, в печати] отмечается, что апрехенсивы (а превентив следует считать частным случаем апрехенсива, см. об этом выше) практически всегда имеют конкретную временну́ю ориентацию (в подавляющем большинстве случаев речь идет о действиях, которые могут произойти в ближайшем будущем или начаться прямо на границе настоящего и будущего) и плохо сочетаются с многократными или хабитуальными событиями. По-видимому, этим обстоятельством объясняется неоднозначная (кажущаяся двойственной) семантика императива СВ в древнеславянских контекстах в тех случаях, когда имеет место референция к ситуации, нелокализованной во времени. В контекстах, описывающих потенциально многократные ситуации (33)-(35), императив CB, по-видимому, выражает совмещение прохибитивной семантики (это значение задается семантикой императива и поддерживается генеричностью ситуации) с превентивной (этот компонент значения задается сочетанием аспектуальной семантики CВ с отрицанием, семантикой неконтролируемости или плохой контролируемости, а также прагматической идеей «пользы для говорящего» ${ }^{10}$ ). В восточнославянском ареале отрицательный императив СВ в контекстах с референцией к обобщенной ситуации встречается, как правило,

${ }^{10}$ B [Wiemer, в печати] выражена интересная мысль о том, что превентивное значение и значение угрозы близки, поскольку предупреждение в действительности является вербализацией угрозы - с той лишь разницей, что угроза преследует интерес говорящего, а превентив - интерес адресата. По-видимому, в рассмотренных в данном разделе неоднозначных контекстах превентивное значение кажется «более ощутимым» — в тех случаях, когда в роли бенефициара выступает адресат (28), (29), (30), а прохибитивное - в тех случаях, когда заинтересованным лицом является говорящий (27), (31). 
в церковнославянских (переводных или ориентированных на них) текстах, содержащих поучения, типа «Изборника 1076 г.» или «Пчелы» (в летописях и берестяных грамотах такие контексты редки или отсутствуют совсем), ср. также контексты типа не убии, рассмотренными ниже в п. 2.3.1:

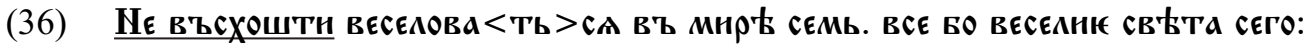
съ пиачьмь коньчавактьса (Изб. 1076, л. 9об.) - «(Смотри) не веселись (букв. Не захоти веселиться) в этом мире, так как все веселие этого мира с плачем заканчивается»;

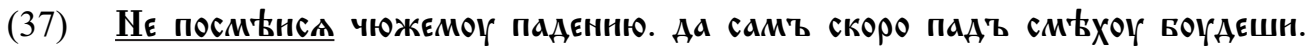

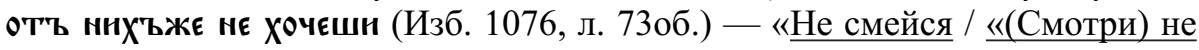
посмейся (букв. Не посмейся) над чужим падением, чтобы, упав, вскоре самому не оказаться осмеянным теми, от кого ты этого не хочешь»;

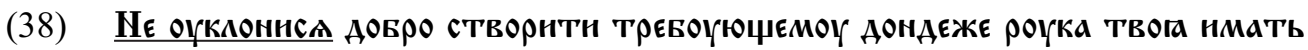
помощь (Пчела, с. 631) — «Не уклоняйся (букв. не уклонись) от благодетельствования нуждающихся, пока рука твоя может помочь»;

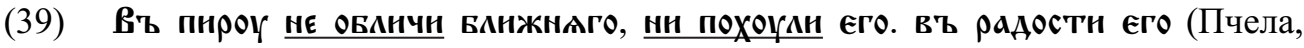
c. 760) — «На пиру (смотри) не обличи ближнего, не обругай его в радости его».

\section{3. Прохибитив СВ}

\subsection{1. Запретительные контексты}

В древнерусских памятниках обнаруживаются и такие контексты, в которых основным у формы отрицательного императива СВ становится не превентивное (предупредительное), а прохибитивное (запретительное) значение: выражается запрет ожидаемых (иногда запланированных) и очевидно контролируемых действий:

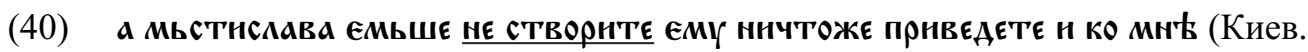
лет., 203об.) - «А схватив Мстислава, не делайте (букв. не сделайте) ему ничего (плохого) и приведите его ко мне», ср. с императивом НСВ в (11);

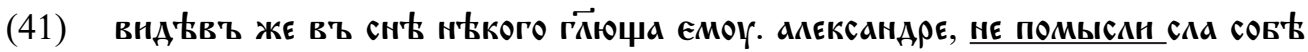
сотворнтн въ тогръ (Александрия, с. 36) - «Увидел же он во сне некоего человека, говорящего ему: “Александр, не вздумай посла отправить в Тур”», ср. с императивом НСВ в (8);

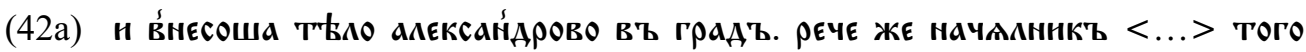

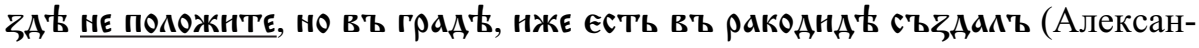
дрия, с. 104) - «И внесли тело Александра в город. Сказал же начальник <...>: “Этого (человека) здесь не кладите (букв. не положите), но в городе, который он создал в Ракодиде”», ср. с императивом НСВ в (42б); 


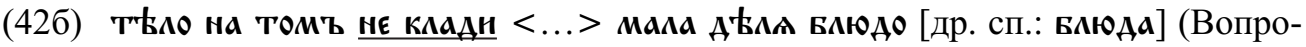
шание, с. 502) — «Тело [Агнца] на этом [блюде] не клади $<\ldots>$, потому что блюдо маленькое»;

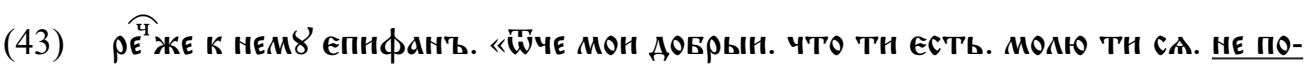
ТАН МЕНЕ. чаАО [В Др. СП.: чаАа Н]. СВОеГО РАБА. ГаКОЖЕ ВНЖЮ ТА ТАКО слезАџа и мокчаща на многы ча ${ }^{c}($ ЖАЮ, 5936-5939, с. 440) - «Сказал же ему Епифан: “Отец мой добрый, Что с тобой? Не утаи от меня, твоего чада и раба, так как вижу тебя плачущим и молчащим долгое время”»;

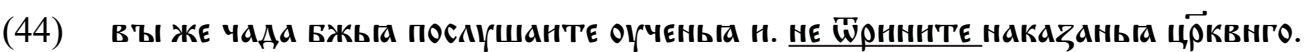

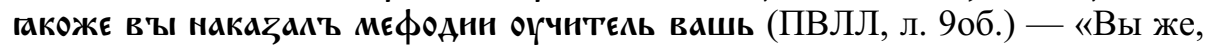
дети Божьи, послушайте учения и не отвергайте (букв. не отвергните) церковного поучения, как вам заповедал Мефодий, учитель ваш»;

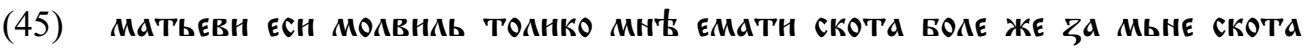
не поустн (НБГ №550, 1180-1200 гг.) — «Ты сказал Матею: “[Лишь] столько (подразумевается: сколько уже собрано) я должен собирать денег (т.е. дани). Больше же ты мне денег не поручай (букв. не поручи)”»;

... - [т]р[н] (г)рн[вьнь] м[ь] отопог(с)тн_(НБГ №676, 1160-1180-е гг.) «... [такой-то должен] три гривны -

В современном русском языке такое функционирование отрицательных императивов $\mathrm{CB}$, как правило, невозможно: при переводе практически во всех случаях СВ приходится менять на НСВ. В древнерусском же языке, по-видимому, еще не сформировались аспектуальные ограничения (превентив - CB vs. прохибитив - НCВ), которые действуют в современном русском языке, но была возможна конкуренция: прохибитив (CB/HCB) vs. превентив (CB/HCB $\left.{ }^{11}\right)$. Представляется, что выбор СВ в приведенных выше контекстах может быть обусловлен чисто аспектуальной семантикой: имеет место референция к единичной ситуации в будущем, соответственно, для каузации ненаступления единичного действия в будущем в древнерусском языке выбирается $\mathrm{CB}^{12}$. НCB же, как было сказано выше (см. п. 1), в древнерусских текстах чаще (хотя и не всегда) употребляется для запрета потенциально многократного действия в ситуации, нелокализованной во времени.

В древнерусских церковнославянских памятниках восточного извода в качестве особого типа следует выделить употребления отрицательного императива СВ в библейских цитатах, восходящих к старославянским переводам. Речь идет об известных контекстах, восходящих к десяти заповедям (не убий, не укради) и подобных им, в которых отрицательный императив выражает запрет действия, нелокализованного во времени:

${ }^{11}$ Вопрос о том, могло ли значение предостережения у форм отрицательного императива НСВ от глаголов с неконтролируемой семантикой (см. п. 2.1) не только сопутствовать семантике запрета, но и выходить на первый план, на наш взгляд, является дискуссионным и требует специального исследования.

${ }^{12}$ В сочетании с отрицанием употребление императива СВ для каузации несовершения единичного действия в будущем возможно в современном словенском языке, см. [Zorikhina Nilsson 2013: 92]. 


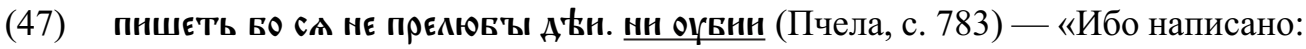
Не прелюбодействуй, не убей».

О таких употреблениях в старославянском см. [MacRobert 2013: 286]. В качестве устойчивых выражений они сохранились и в ряде современных славянских языков (болгарский, сербо-хорватский, чешский, русский), см. [Zorikhina Nilsson 2013: 91]. Очевидно, что в современный русский язык такие употребления проникли из церковнославянского и сохраняются в качестве архаизмов.

\subsection{2. Контексты просьбы и мольбы}

Прохибитивное (а не превентивное) значение отрицательного императива часто реализуется в ситуации просьбы или мольбы. В таких контекстах в древнерусском языке было возможно употребление императива от глаголов НСВ (как и в современном русском), ср.:

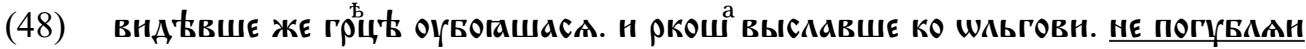

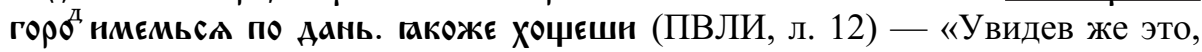
греки испугались и, послав к Олегу, сказали: Не губи город, мы согласимся на дань, какую захочешь»;

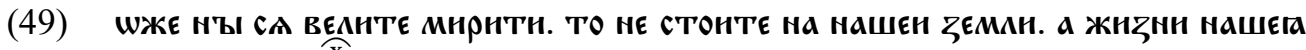

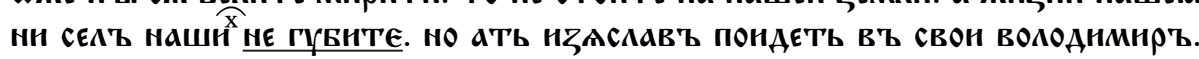
а вЫ въ свою Ђеммю. понднте (КИев. Лет. Л. 141) — «Если вы веЛИТе нам мириться, то не стойте на нашей земле, и жизней наших и сёл не губите, но пусть Изяслав пойдет в свой Владимир, а вы в свою землю пойдите»;

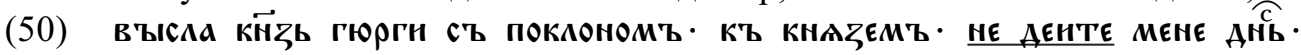
а zабтра пондоу нз города (Новг. І лет., л. 86) - «Выслал князь Гюргий с поклоном к князьям: "Не трогайте меня сегодня, а завтра я уйду из города"»;

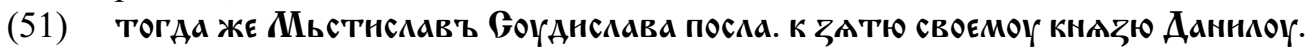

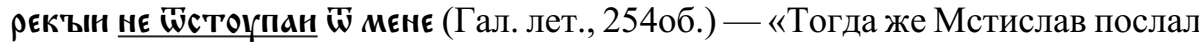
Судислава к зятю своему князю Данилу, говоря: “Не отступайся от меня)”».

В приведенных контекстах отрицательные императивы НСВ выражают запрет на совершение действия в ближайшем будущем. Таким же образом формы отрицательного императива функционируют и в современном русском языке, ср.:

(52) - Не губи семью, Егорушка, деток не губи (НКРЯ: Б. Васильев. Не стреляйте в белых лебедей, 1973).

Наряду с императивами НСВ в контекстах просьбы ${ }^{13}$ могли употребляться и императивы CВ, причем, как показывает статистика, чаще, чем НСВ (приблизительно $60 \%: 40 \%$ ). Возможно, отрицательные императивы СВ преобладали именно

13 Следует оговориться, что в древнерусских текстах не всегда легко отличить просьбы от советов и указаний, поэтому выделение этой группы относительно условно. 
потому, что просьба, как правило, имеет референцию не к обобщенной ситуации (для таких контекстов типичен НСВ), а к конкретной ситуации в будущем ${ }^{14}$, ср.:

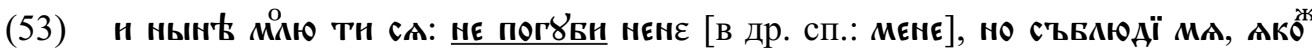
н аъъ та совмюАоХ'ъ (Акир, с. 137) - «И теперь молю тебя: не погуби меня, но сохрани меня в целости, как и я тебя сохранил»;

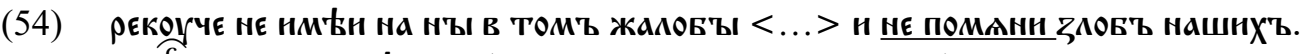
а кртъ к намъ цьиоун (Киев. лет., л. 126, ср. Пс 78:8) - «Говоря: “Не вини нас $<\ldots>$ и не вспоминай (букв. не помяни) наших злых дел, а крест к нам целуй"»;

(55) не створн мн пакостн а се твон кЫєвъ (СУзД. лет., Л. 115об.) - «Не Делай (букв. не сотвори) мне зла, вот Киев твой»;

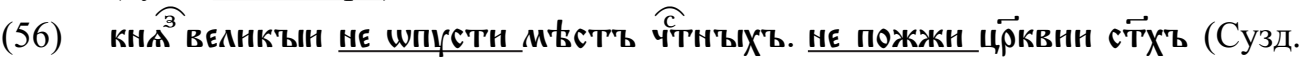
лет., л. 146об.) — «Великий князь, не опустоши мест честных, не пожги церквей святых»;

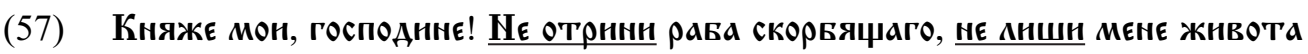
своєго (Даниил Заточник, с. 65) - «Господин, князь мой! Не отвергни раба скорбящего, не лиши меня жизни моей»;

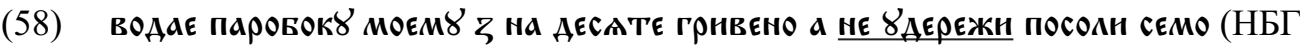
№ 624, 1160-1180-е гг.) - «Выдай слуге моему семнадцать гривен, не откажи (букв.: не удержи [за собой]), [и] пошли сюда»;

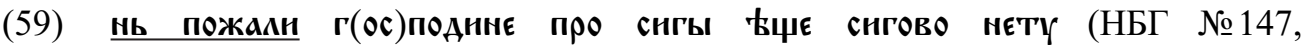
1220-1240-е гг.) - «Не прогневайся, господин, из-за сигов: еще сигов нет».

В древнерусских памятниках формы отрицательного императива СВ в прохибитивном значении довольно часто встречаются в молитвах. Как уже упоминалось выше, в летописи такие формы попадали, очевидно, под влиянием книжного языка, а также в составе цитат (дословных или менее точных) из церковнославянских текстов, прежде всего библейских и богослужебных, ср.:

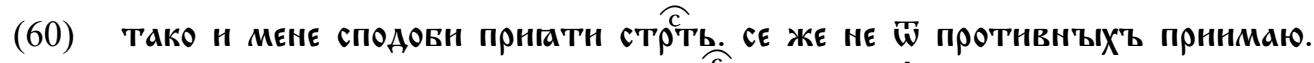

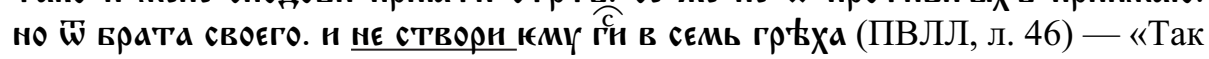
и меня сподобь принять страдания. Я принимаю это не от врагов, но от брата своего. И не сотвори, Господи, ему в этом греха»;

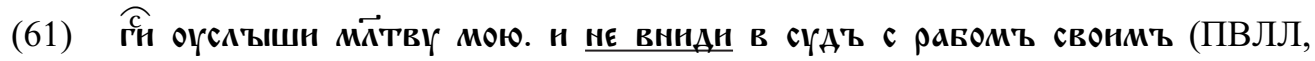
л. 45об., ср. Пс. 142:2) — «Господи, услыши молитву мою и не судись (букв.: не войди в суд) с рабом своим»;

${ }^{14}$ Такая же тенденция наблюдается в контекстах просьбы/мольбы в современном болгарском: преимущественно употребляется $\mathrm{CB}$, а НСВ возможен тогда, когда просьба имеет отношение непосредственно к моменту речи или к возможному повторению действия, см. [Пете 1991: 80]. 


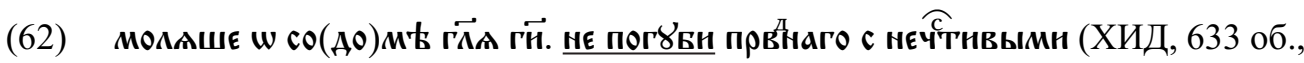
ср. Быт. 18:25) - «(Авраам) молил о Содоме, говоря: Господи, не погуби праведнаго с нечестивыми»;

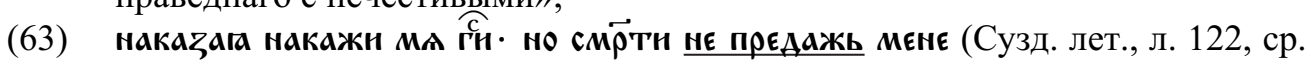
Пс. 117:18) - ср.:

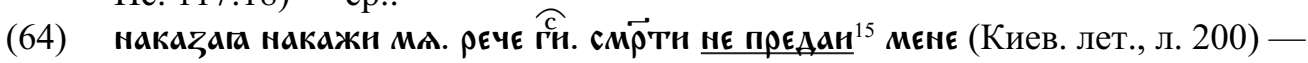
«Наказывая, накажи меня, Господи, но смерти не предай меня»;

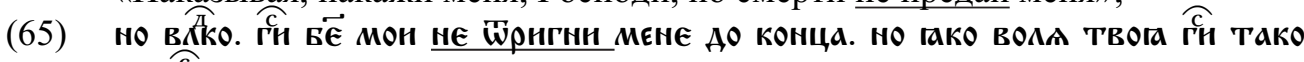
и мкть (Киев. лет., л. 225, ср. Пс. 118:8) - «Но владыко, Господи Боже мои, не отринь меня совершенно, но как воля твоя, Господи, так и милость»;

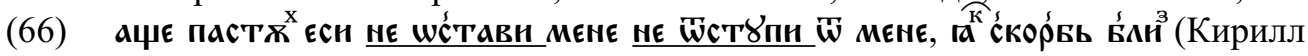
Туровский «Повесть о беспечном царе», л. 80, ср. Пс. 37:22) - «Если Ты пастух, не оставь меня, не отступи от меня, так как скорбь близко».

Ср. с редким употреблением НСВ:

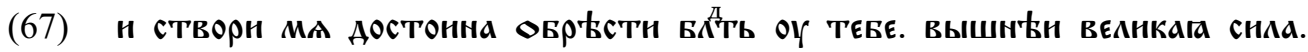
страшнын. не оставлАн насъ (ЖАЮ, 270-272, с. 173) - «И сделай меня достойным получить от Тебя благодать. Вышний, Сильный, Страшный (Господь), не оставляй нас».

В [MacRobert 2013: 287-288] отмечается, что в старославянских текстах имеет место функционально-прагматическая дистрибуция. Подавляющее большинство отрицательных императивов, обращенных к Богу, образованы от глаголов СВ, в то время как отрицательные императивы, обращенные к людям, преимущественно (но не всегда) образованы от глаголов НСВ. В молитвах, обращенных к Богу, древнерусский сходен со старославянским за счет влияния церковнославянских текстов. В просьбах же, обращенных к людям, встречается как СВ, так и НСВ (примерно в равных пропорциях), причем употребление $\mathrm{CB}$, по-видимому, в свою очередь поддерживалось молитвенными контекстами, обращенными к Богу. Следует отметить, однако, что такая прагматическая дистрибуция довольно хорошо вписывается в аспектуальную. Несколько странно предполагать, что Богу можно указывать, прося о чем-то, что он должен делать или не делать всегда или никогда. Соответственно, такие мольбы в текстах редки, а, как было показано выше, именно для генерических и многократных ситуаций типичен $\mathrm{HCB}$, в то время как СВ более характерен в контекстах, имеющих референцию к конкретной ситуации в будущем, как в приведенных выше примерах с просьбами, обращенными как к Богу (60)-(66), так и к людям (53)-(59).

Представляется, что в случае с выбором НСВ (48)-(51), например, не губите (49), акцент смещается на настоящий момент ('прямо сейчас не губи, а также в будущеем'), что порождает эффект «повышающейся актуальности» и «напряженности момента» ("sence of urgency" [Forsyth 1970: 208-209]). Выбор же СВ акцентирует

15 Презентная основа $\partial а j$ - от инфинитива дагати, по всей вероятности, очень рано начала соотноситься с инфинитивом Аатн. 
внимание на конечном результате, то есть в данном случае его ненаступлении: для говорящего актуально, что действие не должно достигнуть результата, то есть не должно ни в коем случае произойти. Кроме того, как уже упоминалось выше, значение отрицательного императива СВ состоит из двух частей (информативной: 'может произойти P' и предписывающей: 'сделай так, чтобы Р не произошло'), а в сферу действия отрицания может попадать только одна из частей [Гусев 2013: 62]. В случае с отрицательным императивом информативная часть не попадает в сферу отрицания, что порождает дополнительный семантический компонент ожидаемости наступления нежелательного события. Дополнительное модальное семантическое наращение «ожидается, что может наступить событие Р», возникающее за счет сочетания СВ с отрицанием, имеет место как в превентивных, так и в прохибитивных контекстах с отрицательным императивом $\mathrm{CB}^{16}$. Все это делает отрицательный императив СВ (по сравнению с НСВ) более категоричным и экспрессивным, ср. не совсем типичное использование отрицательного императива СВ в современном русском языке в рекламных слоганах, эксплуатирующих именно этот эффект категоричности ${ }^{17}$ :

(68) Не позвольте равнодушию победить сочувствие! Помогайте детям! (Социальная реклама, 2019);

Имидж - ничто, жажда все. Не дай себе засохнуть (Sprite, 2000 г.);

Спаси и сохрани Россию. Не допусти красной смуть!! Голосуй за Ельцина!! (Лозунг демократов в кампании по выборам президента, 1996).

В приведенных примерах с отрицательным императивом СВ выражается скорее прохибитивное значение, нежели превентивное. В таком обобщенно-референтном контексте более привычным был бы императив НСВ. Однако императив СВ воспринимается как более категоричный.

Таким образом, как мы попытались показать, семантическая разница между контекстами с отрицательными императивами НСВ и СВ в прохибитивном и превентивном значениях в древнерусском языке была, по-видимому, обусловлена прежде всего различиями в аспектуальной семантике, на которые накладывались дополнительные семантические и прагматические значения.

Следует также отметить, что, по всей вероятности, некоторые из выражений с отрицательным императивом СВ (например, не ими въры, не дай Бог), встречающиеся в ранних памятниках, уже в древнерусский период клишировались и представляли собой устойчивые выражения, ср.:

${ }^{16}$ Данная семантическая особенность объединяет функционирование императива СВ в контексте отрицания с другими глагольными формами (презенс $\mathrm{CB}$, имперфект $\mathrm{CB}$, действ. прич. наст. вр. СВ), у которых под отрицанием также может возникать семантическое наращение «ожидания наступления некоторого неблагоприятного события Р» см. [Мишина 2012; Мишина, в печати].

${ }^{17}$ Такого рода языковая игра на границе возможного и правильного языкового употребления, имеющая целью привлечь внимание, в рекламе не редкость. Ср. относительно недавнюю рекламу Макдональдса 'I am loving it', играющую на обычной неупотребительности глаголов состояния в Present Continuous. 
(69) СТТОСАВЪ ЖЕ ВСЕВОЛОАНЧЬ. СКАШЕТЬ КЪ ГАРОСКАВОУ РЕКА. БРАТЕ НЕ НМН НМЪ вњрљ (Киев. лет., л. 222об.) — «Святослав же Всеволодич посылал к Ярославу, говоря: “Брат, не верь им”»;

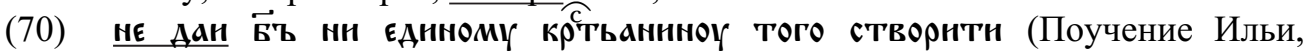
л. 180об.) - «Не дай Бог сотворить этого никакому христианину».

\section{3. Перифрастический прохибитив}

В качестве прохибитивной встречается также достаточно редкая в древнерусских текстах отрицательная инфинитивная конструкция, образованная сочетанием частицы не, формой императива от глагола моџн и инфинитива знаменательного глагола (нє мози / моз'т тє + инф.); о развитии этой конструкции в древнерусском языке см. [Пичхадзе 2008]. Перифрастический прохибитив встречается и в старославянских памятниках ${ }^{18}$. Смысл этой конструкции можно передать примерно так: 'Не смей делать/ни в коем случае не делай $P$ '. В современном русском языке ее аналогом можно считать конструкцию не (вз)думай $(m е)+$ инф. В древнерусском языке перифрастический прохибитив мог образовываться как от глаголов СВ (71)(74), так и НСВ (75)-(78):

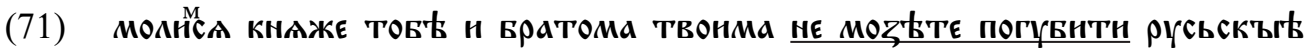
そєммн (ПВЛЛ, л. 88об.) — «Молим, князь, тебя и твоих братьев: не губите/ не вздумайте погубить русскую землю»;

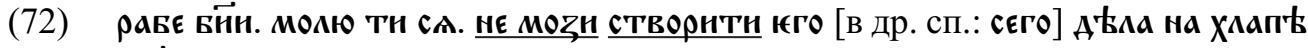
оца мокго (ЖАЮ, 1639-1640, с. 238) - «Раб божий, молю тебя: не смей делать (букв. не сделать) этого с холопом моего отца»;

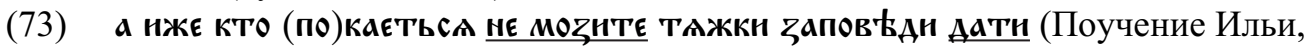
л. 177об.) — «А если кто-то покается, не смейте дать ему тяжелое наказание»;

(74) не моги сл ослоушати (НБГ № 779, 1180-1200 гг.) - «Не смей ослушаться»);

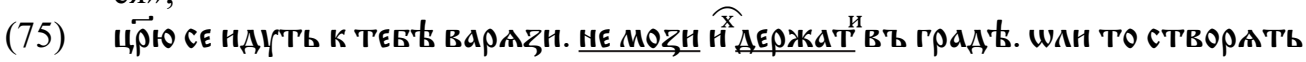
ти зио. гако и сАє (ПВЛЛ, Л. 25) - «Царь, вот идут к тебе варяги. Не вздумай держать их в городе, а не то сотворят тебе зло, как и здесь»;

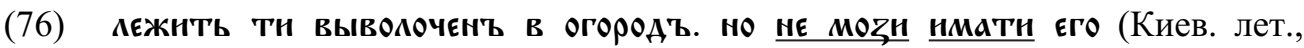
л. 208об.) - «Вот он лежит, выволоченный в огород, но не смей его забирать»;

18 Перифрастический прохибитив является конструкцией праславянского происхождения, причем, по всей вероятности, эта конструкция была прежде всего разговорной: она фиксируется чаще в письменных источниках, отражающих живой язык. В древнейших восточнославянских (как и старославянских) памятниках в этой конструкции встречается только глагол моцн, тогда как в южнославянских языках уже в древности возможны и другие глаголы: хотьтн, д қгатн, врьцин, роднти (см. [Reinhart 1998; Mihaljević, Reinhart 2005]), подробнее, а также ссылки на литературу см. в [Пичхадзе 2008: 233-234]. 


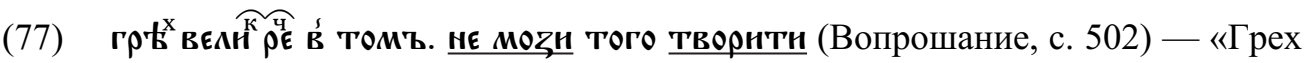
большой, сказал, в этом есть, не смей этого делать»;

(78) Ф снротамъ не моSнте велнкон ШПнтемьн Ааватн (ПоученИе ИльИ, л. 177об.) - «А сиротам не смейте большой епетимьи давать».

В древнерусском языке, по всей вероятности, перифрастический прохибитив выполнял эмфатическую функцию (употреблялся при выражении настоятельной просьбы (71)-(72), настойчивой рекомендации (73), (78) или строгого запрещения (74)-(77) ), придавая высказыванию особою экспрессию. В этой связи кажется показательным, что в данной конструкции инфинитивы от глаголов СВ оказывались более предпочтительными, чем от НСВ: приблизительно 60 \% СВ к 40 \% НСВ), см. статистику по древнерусским памятникам в табл. № 1. Данное обстоятельство кажется не случайным и хорошо согласуется с общей тенденцией функционирования СВ в отрицательных контекстах в древнерусском языке, поскольку, как уже отмечалось выше, во многих случаях формы СВ под отрицанием выступают в качестве более экспрессивных и эмфатически нагруженных по сравнению с формами НСВ. Об эволюции этой конструкции см. п. 5.

CB vs. НСB в перифрастическом прохибитиве

\begin{tabular}{|c|c|c|}
\hline & HE MOZ̈Н + CB & HE MоZ̆ + НCB \\
\hline Повесть временных лет & 1 погоуБнти & 1 Аьржати \\
\hline Поучение Владимира Мономаха & 0 & 1 АБннтнСА \\
\hline Киевская лет. = Суздальская лет. & 1 сътворнтн & 0 \\
\hline Галицкая лет. & $\begin{array}{c}0 \\
\end{array}$ & 1 стрАпати \\
\hline Берестяные грамоты & 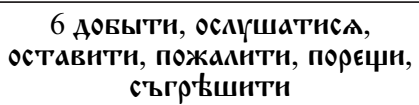 & 0 \\
\hline Поучение Ильи & 3 Аатн, сътворнтн, оуТантн & $\begin{array}{c}3 \text { ААВАТН, ОБАНВАТН, } \\
\text { ОТАГЧАТН }\end{array}$ \\
\hline $\begin{array}{l}\text { Вопрошание Кирика, Саввы } \\
\text { и Ильи }\end{array}$ & 0 & 1 творнти \\
\hline Поучение Луки Жидяты & 0 & 2 СваАнТТ (2 р.) \\
\hline Житие Андрея Юродивого & 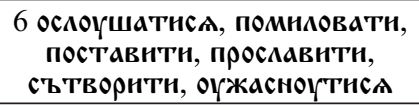 & $\begin{array}{c}6 \text { zаБыватн, крастн, } \\
\text { творнтн, тоужнтн (3 р.) }\end{array}$ \\
\hline Александрия & 1 съмоутнти & 0 \\
\hline Чудеса Николы & $\begin{array}{c}4 \text { ПочюАНТНСА, ПрЕстОУПНТН, } \\
\text { СЪАҚГАТН, ОГТАНТИ }\end{array}$ & 1 Аьннтнск \\
\hline Всего & 22 & 16 \\
\hline
\end{tabular}

${ }^{19}$ Сочетания с инфинитивами от глагольных основ, неохарактеризованных в аспектуальном отношении (нтн, Бнтн, мълвнтн, п⿱宀ти и др.), а также от глаголов, аспектуальную принадлежность которых в силу разных причин (в том числе и из-за низкой частотности) трудно определить однозначно (пов в древнерусский период употреблялись (за редким исключением) как глаголы НСВ (творнти, гАаголатн), включались в число глаголов НСВ. О методике определения аспектуального значения см. в [Мишина 2018]. 


\section{4. Историческое развитие и остаточные свидетельства}

4.1. Следует отметить, что в отрицательных контекстах тенденция к сдвигу выбора в сторону формы императива НСВ прослеживается довольно рано. В целом уже в ранних древнерусских памятниках в контекстах с отрицательным императивом НСВ фиксируется чаще, чем СВ. Ниже в табл. № 2 представлена общая статистика по памятникам, включенным в древнерусский подкорпус НКРЯ. Из таблицы видно, что императив НСВ встречается почти в два раза чаще, чем СВ: при суммарном учете примеров по всем памятникам общее соотношение СВ : НСВ получается приблизительно 38 \% : 62\% с вариациями по отдельным памятникам и жанрам. Так, например, в берестяных грамотах, где много просьб и нет контекстов с референцией к обобщенной ситуации, соотношение СВ : НСВ будет почти равным (52\%: $48 \%$ ).

Таблича № $2^{20}$

CB vs НСB в отрицательном императиве

\begin{tabular}{|c|c|c|c|c|c|}
\hline \multirow{2}{*}{ древнерусские памятники } & \multirow{2}{*}{$\begin{array}{c}\text { Всего } \\
\text { «нє + импер.» } \\
\text { кол-во }\end{array}$} & \multicolumn{2}{|l|}{ CB } & \multicolumn{2}{|c|}{ HCB } \\
\hline & & кол-во & $\%$ & кол-во & $\%$ \\
\hline Пчела & $121 ?$ & $\begin{array}{r}42 ? \text { (+ } 5 \text { не даи; } \\
+4 \text { не рци) }\end{array}$ & $35 \%$ & $79 ?$ & $65 \%$ \\
\hline Повесть об Акире & 47 & $10 \quad \begin{array}{r}\text { (+ } 1 \text { не даи; } \\
\text { (+ } 2 \text { не рци })\end{array}$ & $21 \%$ & 37 & $79 \%$ \\
\hline Киевская летопись & 33 & 13 & $39 \%$ & 20 & $61 \%$ \\
\hline Берестяные грамоты & 33 & 17 (+6 не даи) & $52 \%$ & 16 & $48 \%$ \\
\hline ЖАЮ & $28 ?$ & $10 ?$ & $35 \%$ & 18 & $65 \%$ \\
\hline Суздальская летопись & 26 & 15 & $68 \%$ & 11 & $42 \%$ \\
\hline Поучение Луки Жидяты & 24 & 11 (+2 не даи) & $46 \%$ & 13 & $54 \%$ \\
\hline Поучение Владимира Мономаха & $20 ?$ & 4 & $20 \%$ & 16 & $80 \%$ \\
\hline $\begin{array}{l}\text { Повесть временных лет по Ипа- } \\
\text { тьевскому списку }\end{array}$ & 18 & 6 & $33 \%$ & 12 & $67 \%$ \\
\hline Даниил Заточник & 15 & (+ 2 не даи) & $48 \%$ & 8 & $52 \%$ \\
\hline Александрия & 14 & 7 & $50 \%$ & 7 & $50 \%$ \\
\hline Кирилл Туровский & 12 & 8 & $67 \%$ & 4 & $27 \%$ \\
\hline Чудеса Николы & $11 ?$ & $3 ?$ & $28 \%$ & 8 & $73 \%$ \\
\hline Сочинения Илариона & 10 & 7 & $70 \%$ & 3 & $30 \%$ \\
\hline
\end{tabular}

${ }^{20}$ При подсчете соблюдались принципы, изложенные в сноске 19. Формы императива нє дан (по всей вероятности, эта основа довольно рано начала соотноситься с инфинитивом Аати СB, а не дагати НCB) исключались из общего подсчета форм СВ (статистика по этим формам приведена отдельно в скобках); производные от Аатн (нє прєАан, нє продан) учитывались среди форм СВ. Императивы от глагола рєцн включались в число форм СВ за исключением контекстов, когда нє рьци вводит прямую речь (такие формы из подсчета исключались, данные по ним приведены отдельно в скобках), поскольку в роли маркера прямой речи глагол рєчн, по-видимому, мог сохранять аспектуальную неохарактеризованность, ср. с функционированием действ. прич. наст. времени (рька, рькоучн) [Мишина 2018: 176-177]. Формы императива от глагола быти также исключались из подсчета. Знак «?» при цифре означает, что в данном случае возможна погрешность из-за ошибочности какой-либо из форм. 


\begin{tabular}{|c|c|c|c|c|c|}
\hline \multirow{2}{*}{ древнерусские памятники } & \multirow{2}{*}{$\begin{array}{c}\text { Всего } \\
\text { «нє + импер.» } \\
\text { кол-во }\end{array}$} & \multicolumn{2}{|l|}{ CB } & \multicolumn{2}{|c|}{ HCB } \\
\hline & & кол-во & $\%$ & кол-во & $\%$ \\
\hline История Иудейской войны & 10 & 4 & $40 \%$ & 6 & $60 \%$ \\
\hline Житие Феодосия Печерского & 9 & 2 & $-^{21}$ & 7 & - \\
\hline Новгородская Первая летопись & 9 & 2 & - & 7 & - \\
\hline Галицкая летопись & 6 & 1 (+ 1 не даи) & - & 5 & - \\
\hline Житие Авраамия Смоленского & 6 & 3 & - & 3 & - \\
\hline Поучение Ильи & 5 & $\begin{array}{c}0 \text { (+ } 8 \text { не даи) } \\
(+3 \text { не рци) }\end{array}$ & - & 5 & - \\
\hline Волынская лет. & 4 & 1 & - & 3 & - \\
\hline $\begin{array}{l}\text { Вопрошание Кирика, Саввы } \\
\text { и Ильи }\end{array}$ & 2 & $\begin{array}{c}0(+7 \text { не даи) } \\
(+1 \text { не рци) }\end{array}$ & - & 2 & - \\
\hline Хожение игумена Даниила & $2 ?$ & $2 ?$ & - & 0 & - \\
\hline Житие Леонтия Ростовского & 1 & 1 & - & 0 & - \\
\hline Всего & 466 & 176 & $38 \%$ & 290 & $62 \%$ \\
\hline
\end{tabular}

В позднейших списках отдельных памятников отрицательный императив СВ в прохибитивном значении начинает заменяться на императив НCB:

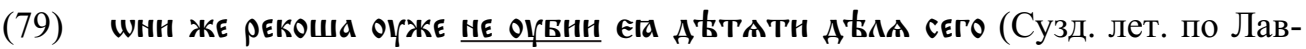
рентьевскому своду 1377 г., л. 100) — «Они же сказали: “Не убивай (букв. Не убей) её ради этого ребенка"».

Cp. тот же контекст в Московском летописном своде, кон. XV в. (по списку

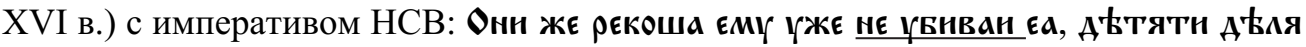
сего (Л. 35об.).

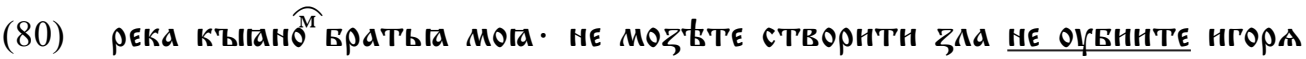
(Сузд. лет. по Лаврентьевскому своду 1377 г., л. 105об.) - «Говоря киевляном: “Братья мои, не делайте зла, не убивайте (букв. не убейте) Игоря”».

Ср. тот же контекст в Киевской летописи с императивом НСВ: рєка кнганомъ

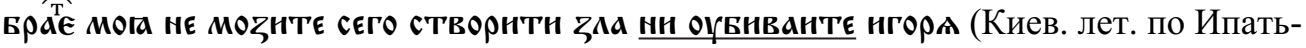
евскому своду ок. 1425 г., л. 129б = МЛС, л. 50).

Однако, несмотря на общую тенденцию к сужению употребления СВ в отрицательном императиве, более свободное, по сравнению с современным русским языком, функционирование отрицательных императивов СВ с прохибитивным значением было возможно еще в XVIII-XIX вв.:

(81) - Да, графиня, потому что не удостоиваете даже и теперь меня ответом. Только двух минут прошу у вас... Грудь моя полна... Не убейте меня отказом, потому что мысль о вашем презрении сведет меня в могилу... (НКРЯ: Н. А. Бестужев. Русский в Париже 1814 года, 1831-1840);

${ }^{21}$ Считать проценты для такого маленького количества примеров не представляется целесообразным. 
(82) Призри их великодушно, не оставь их твоим покровительством, не оставь твоим советом и ту, которая по смерти жень моей им служила вместо матери, не отвергни иногда её прошение, и дай ей наставление (НКРЯ: А.Н. Радищев. Письмо А.Р. Воронцову, 1790);

(83) Устимовичу, Сакену и Хомякову не откажитесь от меня поклон передать (НКРЯ: А.С. Грибоедов. Письма, 1828);

(84) - Oтизы родные, не погубите! И Данилка снова отчаянно застучал лбом об пол (НКРЯ: Н. С. Лесков. Божедомы, 1868).

По-видимому, многие из таких употреблений сохранялись под влиянием церковнославянского языка по аналогии с обращениями к Господу в молитвах (Господи, не оставь меня; Не отвергни моления моего; Не отврати лица Твоего и т. п.), которые, в свою очередь, часто являются цитатами из псалмов (ср. с примерами (60)-(66) из древнерусских памятников), а также библейскими контекстами типа Не убей! Hе укради!, рассмотренными выше (п. 2.3.1). Однако в переводах Библии на современный русский язык (и в синодальном, и в современном, осуществленном Российским библейским обществом в 1995-2010 гг. [Библия 2016]) в подобных случаях часто (хотя и не всегда) выбирается уже императив НСВ, причем в современном переводе НСВ выбирается чаще, чем в синодальном, ср.: не убивай, не кради (синод.) / не воруй (совр.) Исход 20:13-16; не оставь, не удаляйся (синод.) / не покидай (совр.) Пс 37:22, не помяни (синод.) / не вменяй (совр.) Пс 78:8, не оставляй (синод.=совр.) Пс 118:8, не входи в суд (синод.) / не судись (совр.) Пс 142:2 и др.). В современном русском языке употребления императивов СВ сохранились с отдельными глагольными лексемами, как правило, в устойчивых клишированных оборотах типа: Не дай Бог!; Не приведи Господь!; Пожалуйста, не откажите!; Не сочтите за труд; Не погубите! и др.:

(85) Я очень прошу, не откажите в помощи! (НКРЯ: Российский фонд помощи (2002) // «Домовой», 2002.11.04);

(86) - Не откажитесь подсесть к нашему столу, у нас есть для вас интересное дело (НКРЯ: Э. Хруцкий. Операция прикрытия, 1984);

(87) Не дай ему обогнать тебя!

(88) За то, что предупредил - спасибо, я это запомню. - Да уж не оставь старика. - Посиди там полчаса (НКРЯ: П. Галицкий. Цена Шагала, 2000);

(89) Please, не оставьте мой пост без внимания! (НКРЯ: Красота, здоровье, отдых: Красота (форум), 2005).

Остаточные свидетельства более широкого функционирования отрицательного императива СВ на более ранних стадиях развития сохранились в современном русском языке также в разного рода формулах — например заговорах (90) и в условном значении (91):

(90) Или како страшное, ночью во двор ходят: Столп дворяной, хозяин дворовой, меня не устраши, а во сне расскажи (НКРЯ: Арханг. обл., 1994); 
(91) Неизвестно, сколько бы это могло еще продолжаться, не войди mу, где опрашивали Володю, икольный его учитель, сердитьй физик Адам Егорович (НКРЯ: Ю. Герман. Дорогой мой человек, 1961).

Сопоставление статистических данных по формам отрицательного императива СВ и НСВ по различным подкорпусам НКРЯ в хронологической перспективе (см. табл. №3) показывает, что доля СВ в древнерусском и современном русском языке вполне сопоставима (в современном русском она на $10 \%$ меньше), в то время как подкорпус современного церковнославянского языка демонстрирует обратное соотношение СВ : НСВ (примерно 2 : 1), что хорошо соотносится с данными, приведенными выше: большинство контекстов церковнославянского подкорпуса составляют молитвы, для которых типичен СВ.

Табли иза № $3^{23}$

\begin{tabular}{|c|c|c|c|c|c|}
\hline & \multirow{2}{*}{$\begin{array}{c}\text { Всего } \\
\text { не + императив }\end{array}$} & \multicolumn{2}{|c|}{ CB } & \multicolumn{2}{|c|}{ HCB } \\
\hline & & кол-во & $\%$ & кол-во & $\%$ \\
\hline Древнерусский подкорпус НКРЯ+24 & 466 & 176 & $38 \%$ & 290 & $62 \%$ \\
\hline $\begin{array}{l}\text { Основной подкорпус НКРЯ } \\
\text { (современный рус. яз.) }\end{array}$ & 6333 & 1654 & $26 \%$ & 4679 & $74 \%$ \\
\hline $\begin{array}{l}\text { Церковнославянский подкорпус НКРЯ (сов- } \\
\text { ременный церковнослав. яз.) }\end{array}$ & 3402 & 2317 & $68 \%$ & 1085 & $32 \%$ \\
\hline
\end{tabular}

4.2. Исследование употребления перифрастического прохибитива в диахронической перспективе показывает, что в истории русского языка в данной конструкции имела место ожидаемая тенденция к сужению функционирования форм СВ и постепенной экспансии НСВ. Как в древнерусский, так и в старорусский период формы инфинитива СВ преобладают над инфинитивом НСВ (приблизительно 60 \% СВ : $40 \%$ НСВ). В старорусском подкорпусе НКРЯ (в этот период более употребительной становится форма нє могн(тє)) обнаруживается 20 контекстов с $\mathrm{CB}^{25}$ на 14 контекстов с НСВ. В XIX в. данная конструкция была еще вполне живой (хотя, возможно, уже и просторечной); в качестве формы императива употребляется форма ед. ч. не моги (форма мн. ч. не могите встретилась всего несколько раз в НКРЯ), см. (92)-(93). В современном же русском перифрастический прохибитив перестает

22 Об этой конструкции см. [Holvoet 2018].

${ }^{23}$ В таблице приведены точные цифры, однако надежность статистических данных всё же может быть оценена лишь приблизительно. По отношению к древнерусскому языку мы сталкиваемся со сложностями, касающимися в некоторых случаях неоднозначности в определении аспектуального значения. Что же касается современного русского языка, то, к сожалению, статистические данные по НКРЯ, подсчитанные автоматически, не лишены определенной погрешности (так, например, они включают примеры, ошибочно продублированные в корпусе).

24 В подсчетах учитывались данные не только тех памятников, которые выложены в древнерусский подкорпус НКРЯ, но также и тех, которые на данный момент в открытый доступ еще не выложены (см. табл. 2).

25 Включенный в данную статистику глагол рещи, некоторые формы которого свидетельствуют о его былой неохарактеризованности (см. [Мишина 2018: 176-177]), для старорусского периода мы считаем уже глаголом СВ. 
употребляться в литературном языке, однако продолжает иногда использоваться в разговорной речи, а также в художественной литературе в качестве элемента, используемого для языковой игры или стилизации речи персонажа (94)-(95). Начиная с XIX в., соотношение форм инфинитива СВ : НСВ в данной конструкции становится обратным древнерусскому: НСВ встречается примерно вдвое чаще, чем СВ. По данным НКРЯ (основной, устный, газетный, поэтический подкорпуса) на приблизительно 145 случаев форм НСВ приходится ок. 70 форм СВ:

(92) Если же там какая-нибудь станет до свадьбы добираться - боже сохрани! не моги и подумать (СВ)! (НКРЯ: Гончаров. Обыкновенная история, 1847);

(93) Никак ты плакать сбираешься? И думать (НСВ) не моги! (НКРЯ: А. Н. Островский. Свои люди - сочтемся, 1849);

(94) И в уме не держи, батюшка! Пальцем тронуть (СВ) меня не моги. Уймись лучше! (НКРЯ: Ф.В. Гладков. Повесть о детстве, 1948);

(95) Укошки четыре ноги,

Позади нее длинный хвост,

Но трогать (НСВ) ее не моги

За ее малый рост, мальй рост (фольклорный текст).

\section{Выводы}

Проведенный анализ показывает, что в древнерусском языке (на раннем этапе) еще не сформировалась функциональная оппозиция «превентив (CB) vs. прохибитив (НСВ)», вырисовывающаяся довольно чётко в современном русском языке. В сочетании с отрицанием императив от глаголов СВ не обязательно имел значение превентива, но мог также выражать прохибитивное значение - некоторые лексемы сохранили такие употребления до наших дней (часто как устаревшие). Кроме того, границы между превентивами и прохибитивами были более размытыми: в ряде случаев можно говорить о синкретичном сочетании этих значений в одной форме. Семантическая разница между контекстами с отрицательными императивами НСВ и СВ в древнерусском языке была, по-видимому, обусловлена прежде всего различиями в аспектуальной семантике, на которые накладывались дополнительные семантические и прагматические значения, что в целом согласуется с гипотезой, высказанной в [Вимер 2015: 587] о том, что историческое развитие оппозиции СВ : НСВ развивалось в направлении от более объективных функций (например, акциональные свойства или кратность) к более субъективным (прагматическим). Можно также констатировать, что в прохибитивных контекстах форма отрицательного императива СВ, по-видимому, была эмфатически более нагруженной по сравнению с императивом НСВ.

На основании сравнения функционирования отрицательного императива в древнерусском и современном русском языке можно сделать вывод о том, что СВ в императиве под отрицанием в целом сузил свой функциональный (иллокутивный) диапазон и стал употребляться реже. Прежде всего он был вытеснен из сферы 
прохибитива, в то время как $\mathrm{HCB}$, напротив, был ограничен прохибитивными значениями, что согласуется с общим направлением развития функционирования отрицательного императива в других славянских языках, см. [Wiemer, в печати].

\section{Источники}

Акир - Григорьев А. Д. Повесть об Акире Премудром. Исследование и тексты. M., 1913.

Александрия - Истрин В.М. Александрия русских хронографов. Исследование и текст. М., 1893. С. 5-105.

Библия. Современный русский перевод: [Пер. с древнеевр., арам. и древнегреч.]. М.: Российское Библейское общество, 2016.

Вол. лет. - Волынская летопись // Полное собрание русских летописей. Т. 2. Ипатьевская летопись. М., 2001. С. 848-938.

Гал. лет. - Галицкая летопись // Полное собрание русских летописей. Т. 2. Ипатьевская летопись. М., 2001. С. 715-848.

Даниил Заточник - Слово и Моление Даниила Заточника // Слово Даниила Заточника по редакциям XII и XIII вв. и их переделкам / Приготовил к печати Н. Н. Зарубин. Л., 1952.

ЖАЮ - Житие Андрея Юродивого // Молдован. А. М. Житие Андрея Юродивого в славянской письменности. М. 2000. С. 159-450.

Житие Авраамия Смоленского - Житие Авраамия Смоленского. По списку ГИМ, Уваров. № 350-1ํ, XVI в., л. 322-343.

Житие Леонтия Ростовского - Житие Леонтия, епископа Ростовского. По списку РГБ, ф. 304 (Тр.-Серг. Лавры), № 745, л. 94-97об.

ЖФП - Житие Феодосия Печерского // Успенский сборник XII-XIII вв. М., 1971. С. $71-135$.

Изб. 1076 - Изборник 1076 года / Изд. подгот. М. С. Мушинская, Е. А. Мишина, В.С. Голышенко. 2-е изд., перераб. и доп. Т. І. М., 2009.

ИИВ - «История иудейской войны» Иосифа Флавия. Древнерусский перевод / Изд. подгот. А.А. Пичхадзе, И.И. Макеева, Г.С. Баранкова, А. А. Уткин. T I.M., 2004. С. 63-684.

Иларион - Сочинения Илариона, митрополита Киевского («Похвала Владимиру», «Молитва», «Исповедание веры»). По списку ГИМ, Син. 591, 2-я пол. XV в.

Киев. лет. - Киевская летопись / Изд. подгот. И. С. Юрьева. М., 2017.

Вопрошание - Вопрошание Кирика, Саввы и Ильи // Мильков В. В., Симонов $P . A$. Кирик Новгородец: ученый и мыслитель (=Памятники древнерусской мысли: исследования и тексты. Вып. VII). М., 2011. С. 358-534.

МЛС - Московский летописный свод конца XV века // Полное собрание русских летописей. Т. 25. Изд. 2-е. М.; 2004.

НБГ - Новгородские берестяные грамоты // Зализняк А. А. Древненовгородский диалект. 2-е изд. М., 2004.

НКРЯ - Национальный корпус русского языка. URL: http://www.ruscorpora.ru/ 
Новг. І лет. - Новгородская Первая летопись старшего извода по Синодальному списку // Полное собрание русских летописей. Т. 3. Новгородская Первая летопись старшего и младшего извода. М., 2000.

ПВЛЛ - Повесть временных лет по Лаврентьевскому списку // Полное собрание русских летописей. Т. 1. Лаврентьевская летопись. М., 2001.

ПВЛИ - Повесть временных лет по Ипатьевскому списку // Полное собрание русских летописей. Т. 2. Ипатьевская летопись. М., 2001.

Поучение Влад. Мономаха - Поучение Владимира Мономаха // Полное собрание русских летописей. Т. 1. М., 2001. С. 240-256.

Поучение Ильи - Поучение Ильи Иоанна // Попов А. Неизданный памятник русского церковного права ХІІ в. // ЖМНП. 1890. Ч. 271. № 10 (октябрь). Отд. II. C. $275-300$.

Поучение Луки Жидяты - Мильков В.В. Поучение Луки Жидяты: идейно-религиозное своеобразие и политическая подоплека [Электронный ресурс] // Язык и текст langpsy.ru. 2018. Том 1. №1. URL: http://psyjournals.ru/langpsy/2018/n1/ Milkov.shtml (дата обращения: 22.11.2019). С. 83-92.

Пчела - «Пчела»: Древнерусский перевод / Изд. подгот. А.А. Пичхадзе, И.И. Макеева. Т.І. М., 2008.

Сузд. лет. - Суздальская летопись // Полное собрание русских летописей. Т.І. Лаврентьевская летопись. М., 2001.

Кирилл Туровский - Сочинения Кирилла Туровского: Повесть о беспечном царе его мудром советнике (по списку ГИМ, Синод. № 935, XVI в.); Притча о душе и теле (по списку ГИМ, Чуд. 20, XIV в.); Сказание о черноризском чине (по списку ГИМ, Синод. № 132 (Новгородская или Климентовская кормчая), XIII в.), по древнерусскому подкорпусу НКРЯ.

ХИД - Хожение игумена Даниила. По списку ГИМ, Синод., № 181, XVI в.

Чудеса Николы - Цикл из восьми чудес Николая мирликийского. По списку РНБ F.п.1, 46, кон. XII в. (по древнерусскому подкорпусу НКРЯ).

\section{Литература}

Бирюлин Л.А., Храковский В.С. Повелительные предложения: проблемы теории // Типология императивных конструкций. СПб, 1992. С. 5-50.

Бульгина T.B. К построению типологии предикатов в русском языке // Семантические типы предикатов. М., 1982. С. 20-39.

Вимер Б. О роли вида в области кратности и прагматических функций (эскиз с точки зрения хронотопии) // Глагольный вид: грамматическое значение и контекст $=$ Verbalaspect: Grammatical meaning and context / R. Benacchio (ред.). München, 2015. C. 586-609.

Гусев В. Ю. Типология императива. М., 2013.

Добрушина Н. Р. Грамматические формы и конструкции со значением опасения и предостережения // Вопросы языкознания. 2006. №2 . С. 28-67.

Добрушина Н.Р. Императив. 2014. URL: www.rusgram.ru 
Добрушина Н.Р., Даниэль М.А. Русская частица смотри в типологическом освещении // Динамические модели: Слово. Предложение. Текст. Сб. статей в честь Е. В. Падучевой. М., 2008. С. 293-308.

Зализняк Анна А. Презенс совершенного вида в значении настоящего времени // Зализняк Анна А., Микаэлян И.Л., Шмелёв А.Д. Русская аспектология: В защиту видовой пары. М., 2015. С. 314-329.

Зализняк Анна А., Шмелев А.Д. Введение в русскую аспектологию. М., 2000.

Мишина E.A. «Ситуация напрасного ожидания» и отрицание // Русский язык в научном освещении. 2012. № 2 (24). С. 219-241.

Мишина E.A. К вопросу о видовой семантике простых (бесприставочных) глаголов в древнерусском языке // Русский язык в научном освещении. № 1 (35). 2018. C. $161-182$.

Мишина E.A. Влияние отрицания на функционирование видо-временных форм в древнерусском языке // Русский язык в научном освещении. 2020. № 1 (В печати).

Падучева Е. В. Русское отрицательное предложение. М., 2013.

Падучева E. B. Семантические исследования. Семантика времени и вида в русском языке. Семантика нарратива. М., 1996.

Пете. И. Употребление глаголов совершенного вида в болгарских и русских отрицательных и побудительных предложениях // Съпоставително езикознание / Сопоставительное языкознание / Contrastive linguistics 1991. Vol. 16 (2). C. 17-21.

Пичхадзе А.А. Перифрастический прохибитив в древнерусском // Miscellanea Slavica. Сб. статей к 70-летию Бориса Андреевича Успенского. М., 2008. С. 228-238.

Храковский В.С., Володин А.П. Семантика и типология императива. Русский императив. Л., 1986.

Forsyth, J.A. Grammar of Aspect: Usage and Meaning in the Russian Verb. Cambridge, 1970.

Holvoet, A. Sources for historical imperatives // Acta Linguistica Hafniensia, Vol. 50. 2018. P. 36-51.

MacRobert C. M. The problem of the negated imperative in Old Church Slavonic // Miklosichiana Bicentennalia. Zbornik u čast dvestote godišnjice rođenja Franca Miklošiča. Belgrade, 2013. P. 277-291.

Mihaljević M., Reinhart J. The Croatian Redaction: Language and Literature // Incontri linguistici. 28. 2005. P. 31-82.

Reinhart $J$. Peryfrastyczne wyrażenie zaprzeczonego trybu rozkazującego w języku cerkiewno-slowiańskim: ne brězi + bezokolicznik // Tєматү. Księga jubileuszowa w 70. rocznicę urodzin profesora Leszka Moszyńskiego. Gdańsk, 1998. S. 173-179.

Wiemer B. Major apprehentional strategies in Slavic: a survey of their areal and grammatical distribution (forthcoming).

Zorikhina Nilsson $N$. The negated imperative in Russian and other Slavic languages. Aspectual and modal meanings // Diachronic and Typological Perspectives on Verbs (=Studies in Language Companion Series 134) / Ed. by F. Josephson and I. Söhrman. 2013. P. 79-106. 


\section{Ekaterina A. Mishina \\ Vinogradov Russian Language Institute of the Russian Academy of Sciences \\ (Moscow, Russia) \\ kmishina@mail.ru}

\section{THE NEGATED IMPERATIVE IN OLD RUSSIAN}

This article is devoted to the study of the functions of the forms of the negated imperative in Old Russian. In modern Russian, the negated imperative is mainly imperfective. Moreover, negated imperatives of different aspects have different meanings: the imperfective imperative has a prohibitive meaning, whereas the perfective imperative has a preventive meaning. In Old Russian, the negated imperfective imperative also dominates, although the negated perfective imperative is used more widely than in modern Russian. Research reveals that the functional opposition of preventive (Pfv.) vs prohibitive (Impfv.), which is a clear general trend in modern Russian, was not yet fully formed in Old Russian. Old Russian texts, in comparison with modern Russian ones, demonstrate more free aspectual competition in negative contexts: the functional differences between forms of negated Pfv. and Impfv. imperatives were largely based on the differences in their aspectual semantics. Pragmatic functions were an additional component. Subsequently, in the process of its historical development, the perfective aspect has narrowed its functionality and become less commonly used with negated imperatives.

Keywords: negation, imperative, periphrastic imperative, preventive, prohibitive, verbal aspect, Old Russian.

\section{References}

Biryulin L.A., Khrakovskiy V.S. Povelitel'nye predlozheniya: problemy teorii. Tipologiya imperativnykh konstruktsiy. St. Petersburg, 1992. S. 5-50.

Bulygina T.V. K postroeniyu tipologii predikatov v russkom yazyke. Semanticheskie tipy predikatov. Moscow, 1982. S. 20-39.

Dobrushina N.R. Grammaticheskie formy i konstruktsii so znacheniem opaseniya i predosterezheniya. Voprosy yazykoznaniya. 2006. №2. S. 28-67.

Dobrushina N. R. Imperativ. 2014. URL: www.rusgram.ru

Dobrushina N.R., Daniel' M.A. Russkaya chastitsa smotri v tipologicheskom osveshchenii. Dinamicheskie modeli: Slovo. Predlozhenie. Tekst. Sbornik statey v chest' E. V. Paduchevoy. Moscow, 2008. S. 293-308.

Forsyth, J.A. Grammar of Aspect: Usage and Meaning in the Russian Verb. Cambridge, 1970.

Gusev V. Yu. Tipologiya imperativa. Moscow, 2013.

Holvoet, A. Sources for historical imperatives. Acta Linguistica Hafniensia. Vol. 50. 2018. P. 36-51. 
Khrakovskiy V.S., Volodin A.P. Semantika i tipologiya imperativa. Russkiy imperativ. Leningrad, 1986.

MacRobert C. M. The problem of the negated imperative in Old Church Slavonic. Miklosichiana Bicentennalia. Zbornik u čast dvestote godišnjice rođenja Franca Miklošiča. Belgrade, 2013. P. 277-291.

Mihaljević M., Reinhart J. The Croatian Redaction: Language and Literature. Incontri linguistici. 28. 2005. P. 31-82.

Mishina E. A. «Situatsiya naprasnogo ozhidaniya» i otritsanie. Russkiy yazyk v nauchnom osveshchenii. 2012. №2 (24). C. 219-241.

Mishina E. A. K voprosu o vidovoy semantike prostykh (bespristavochnykh) glagolov v drevnerusskom yazyke. Russkiy yazyk v nauchnom osveshchenii. № 1 (35). 2018. S. 161-182.

Mishina E.A. Vliyanie otritsaniya na funktsionirovanie vido-vremennykh form $\mathrm{v}$ drevnerusskom yazyke. Russkiy yazyk v nauchnom osveshchenii. 2020. № 1 (forthcoming).

Paducheva E. V. Russkoe otritsatel'noe predlozhenie. Moscow, 2013.

Paducheva E. V. Semanticheskie issledovaniya. Semantika vremeni $i$ vida v russkom yazyke. Semantika narrativa. Moscow, 1996.

Pete. I. Upotreblenie glagolov sovershennogo vida $\mathrm{v}$ bolgarskikh i russkikh otritsatel'nykh i pobuditel'nykh predlozheniyakh. S"postavitelno ezikoznanie / Sopostavitel'noe yazykoznanie / Contrastive linguistics. 1991. Vol. 16 (2). S. 17-21.

Pichkhadze A. A. Perifrasticheskiy prokhibitiv v drevnerusskom. Miscellanea Slavica. Sb. statey k 70-letiyu Borisa Andreevicha Uspenskogo. Moscow, 2008. S. 228-238.

Reinhart J. Peryfrastyczne wyrażenie zaprzeczonego trybu rozkazującego w języku cerkiewno-slowiańskim: ne brězi + bezokolicznik. Temaттy. Księga jubileuszowa w 70. rocznice urodzin profesora Leszka Moszyńskiego. Gdańsk, 1998. S. 173-179.

Vimer B. O roli vida v oblasti kratnosti i pragmaticheskikh funktsiy (eskiz s tochki zreniya khronotopii). Glagol'nyy vid: grammaticheskoe znachenie $i$ kontekst $=$ Verbalas pect: Grammatical meaning and context. R. Benacchio (red.). München, 2015. S. 586609.

Wiemer B. Major apprehentional strategies in Slavic: a survey of their areal and grammatical distribution (forthcoming).

Zaliznyak Anna A. Prezens sovershennogo vida v znachenii nastoyashchego vremeni. In: Zaliznyak Anna A., Mikaelyan I. L., Shmelev A.D. Russkaya aspektologiya: V zashchitu vidovoy pary. Moscow, 2015. S. 314-329.

Zaliznyak Anna A., Shmelev A.D. Vvedenie v russkuyu aspektologiyu. Moscow, 2000.

Zorikhina Nilsson N. The negated imperative in Russian and other Slavic languages. Aspectual and modal meanings. Diachronic and Typological Perspectives on Verbs (=Studies in Language Companion Series 134). Ed. by F. Josephson and I. Söhrman. Amsterdam; Philadelphia, 2013. P. 79-106. 